\title{
Struggles Experienced by Religious Minority Families in the United States
}

Loren D. Marks

Brigham Young University - Provo, loren_marks@byu.edu

David C. Dollahite

Brigham Young University - Provo

Kaity Pearl Young

Utah State University

Follow this and additional works at: https://scholarsarchive.byu.edu/facpub

Part of the Other Social and Behavioral Sciences Commons

\section{Original Publication Citation}

Marks, L. D., Dollahite, D. C., \& *Young, K. P. (2019). Struggles experienced by religious minority families in the United States: Strangers in their own land. Psychology of Religion and Spirituality, 11, 247-256.

\section{BYU ScholarsArchive Citation}

Marks, Loren D.; Dollahite, David C.; and Young, Kaity Pearl, "Struggles Experienced by Religious Minority Families in the United States" (2018). Faculty Publications. 4832.

https://scholarsarchive.byu.edu/facpub/4832

This Peer-Reviewed Article is brought to you for free and open access by BYU ScholarsArchive. It has been accepted for inclusion in Faculty Publications by an authorized administrator of BYU ScholarsArchive. For more information, please contact ellen_amatangelo@byu.edu. 


\title{
Struggles Experienced by Religious Minority Families in the United States
}

\author{
Loren D. Marks and David C. Dollahite \\ Brigham Young University
}

Kaity Pearl Young
Utah State University

\begin{abstract}
More than a thousand empirical studies report positive correlations between religious involvement and various aspects of psychological, relational, or physical health. Even so, there are also substantial costs, challenges, and negative aspects of religious involvement that warrant scholarly attention, including religion-related oppression and discrimination. The objective of this study was to provide an in-depth exploration and qualitative analysis of religion-related struggles experienced by religious minorities. A national sample of 198 diverse, religious families ( $N=476$ participants) were interviewed. Of the 198 families, $131(66 \%)$ were from religious minority communities (i.e., Jewish, Muslim, or Christian minority faiths) and serve as the sample and focus of this study. Team-based qualitative analyses indicated five recurring, religion-related sources of struggle that originated "outside the family." Core themes included (1) struggles related to difference and minority status, (2) struggles related to other religious people, (3) struggles related to misunderstanding and ignorance, (4) struggles related to the demands of the faith community, and (5) struggles related to animosity and rejection. Supporting primary data are presented to illustrate each of the five themes. From a research vantage, religious minorities are posited as a rich but often overlooked context for studying religious struggles. In terms of clinical practice, the vital import of awareness and sensitivity to religio-cultural context is underscored. With respect to educational application, pragmatic exercises that help students cross over the "empathy wall" with respect to religious minorities are recommended.
\end{abstract}

Keywords: religion, minority, struggles, empathy, qualitative

More than a thousand empirical studies report positive correlations between religious involvement and various aspects of psychological, relational, or physical health (Koenig, King, \& Carson, 2012; Mahoney, 2010; Marks \& Dollahite, 2011). Consistent with recurring findings in the broader religion-health literature, correlations between religion and familial relational health have typically been positive in nature-although often weaker in magnitude than individual-level findings (Marks, 2006). Addressing family level research, Mahoney (2010) noted that higher religiousness seems to help with both formation and maintenance of traditional family bonds. Even so, there are also substantial costs, challenges, and negative aspects of religious involvement that warrant scholarly attention (including religion-related oppression and discrimination), and scholars of religion have urged balanced and careful examination of these struggles as well (Ellison \& Lee, 2010; Exline, 2013; Koenig et al., 2012).

Recent work has identified complex religious/spiritual struggles as both a cause and effect of distress (Pirutinsky, Rosmarin, Pargament, \& Midlarsky, 2011), while others have noted that some religious and spiritual struggles can be profound enough to impair

This article was published Online First July 16, 2018.

Loren D. Marks and David C. Dollahite, School of Family Life, Brigham Young University; Kaity Pearl Young, Marriage and Family Therapy, Utah State University.

Correspondence concerning this article should be addressed to Loren D. Marks, School of Family Life, Brigham Young University, 2092C JFSB, Provo, UT 84602. E-mail: loren_marks@byu.edu emotional and psychological health (Exline, 2013; Exline, Pargament, Grubbs, \& Yali, 2014; Exline, Park, Smyth, \& Carey, 2011; Grubbs, Exline, \& Campbell, 2013). The examination of religious/ spiritual struggles has garnered expanding attention, but participants in more sophisticated (e.g., longitudinal) studies have been almost exclusively Christian (Pirutinsky et al., 2011). Lesser attention to religious minority persons and families is unfortunate, given the often unique challenges and struggles religious minorities face in both public and private spheres-including, for example, the workplace challenges of Muslims (Alghafli, Marks, Hatch, $\&$ Rose, 2017) and personal negative religious coping that seems to lead to depression among some Orthodox Jews (Pirutinsky et al., 2011). Furthermore, both family stressors (e.g., parenting) and religious struggles seem to have substantial cross-cultural variance, increasing the need for nuanced study of related phenomena (Pirutinsky, Schechter, Kor, \& Rosmarin, 2015). We explore the relational struggles experienced by highly religious families in the United States, with focused attention on families in minority faiths.

In this article, we operationally define a religious minority as one comprising less than $5 \%$ of the U.S. population and not falling under a Catholic, Mainline Protestant, or Evangelical Protestant umbrella. Examples include Judaism, Islam, Latter-day Saint (Mormon), and Jehovah's Witness denominations. Relational Struggles Linked to Religion (hereafter struggles) are relational challenges and conflicts that participants connected to religion.

Next, in brief overview, two topics will be addressed: (1) social science research on religious struggles and (2) social science research on religious struggles among minorities. 


\section{Social Science Research on Religious Struggles}

A weakness in social science research on religion has been a failure to address the question of how religion can harm family relationships and introduce controversies and struggles into relational contexts (Dollahite, Marks, \& Dalton, 2018; Mahoney, 2010). Burr, Marks, and Day (2012) found this latter point sufficiently significant that it was featured in the opening sentence of their book-length review addressing "ways the sacred parts of the human experience help and harm families" (p. vii, emphasis added).

Exline was among the first to systematically and empirically examine struggles to explain negative experiences that occur in relation to religious or spiritual beliefs or practices (Exline, 2002; Exline et al., 2014). Recent literature on religious and spiritual struggles has addressed three main domains: (a) supernatural (e.g., divine or demonic struggles), (b) intrapersonal struggles (e.g., morality-, meaning-, and doubt-related struggles), and (c) interpersonal struggles. Empirical studies of religious and spiritual struggles (e.g., Exline, 2013), however, have focused mainly on negatively perceived relationships with God (the supernatural domain). Comparatively little research has addressed the intrapersonal and interpersonal struggles domains. While examples of the first two domains (supernatural and intrapersonal struggles) did appear in our data, the latter domain of interpersonal (or relational) struggles was most prevalent and is the focus of the current study.

Quantitative studies of interpersonal struggles have examined religious conflict arising between members of a religious community (Ellison, Krause, Shepherd, \& Chaves, 2009; Krause, Chatters, Meltzer, \& Morgan, 2000), or any conflict with religious people, with religious institutions, or with other persons regarding religious topics (Exline et al., 2014). Qualitative studies on interpersonal struggles relating to religion are more rare (e.g., Dollahite, Marks, \& Young, 2018; Becker, 1999). Furthermore, Exline (2013) has reported that most of the empirical literature on religious struggles has examined mental and physical health outcomes, some of which have been found to be negative (Abu-Raiya \& Pargament, 2015; Koenig et al., 2012; McConnell, Pargament, Ellison, \& Flannelly, 2006). Many studies also focus on a group wrestling with a particular stressor (e.g., cancer patients; e.g., Abu-Raiya, Pargament, Krause, \& Ironson, 2015). Another related point is that most studies on religious struggles focus on one domain of struggle (either divine, intrapersonal, or interpersonal; Ellison \& Lee, 2010). We now focus our attention on religious struggles among minorities.

\section{Social Science Research on Struggles Among Religious Minorities}

As previously noted, some religious and spiritual struggles can be profound enough to impair emotional and psychological health (Exline, 2013; Exline et al., 2011, 2014; Grubbs et al., 2013). Religion-related struggles, including discrimination, take place interpersonally and in employment settings (Burstein, 1991; Wilt, Grubbs, Exline, \& Pargament, 2016). Notably, religious discrimination claims in the workplace have more than doubled over the last 20 years, with many of these claims coming from religious minorities (Cantone \& Wiener, 2017). In spite of increasing religious divergence and diversity in the United States, most U.S. citizens still suffer from what Prothero (2009) has called religious illiteracy — and this lack of awareness has likely served as a barrier to tolerance, understanding, and respect. This lack of awareness is reflected in the relatively limited body of social science research on struggles among religious minorities, with one review stating that one of the most conspicuous gaps in the literature is a paucity of research on non-Christian religions (Dollahite, Marks, \& Goodman, 2004). This is unfortunate given that religious minority individuals and families likely offer the richest context for studying religious struggles. Indeed, in the words of William James (1902/1997), the father of the psychology of religion, "We may learn most about a thing when we view it . . . in its most exaggerated form. This is as true of religious phenomena as of any other kind. [F]ainter manifestations may tranquilly pass by" (p. 48). Our application of James' reasoning is that valuable reports of religious struggles are likely to come from those whose religion positions them in an often discriminated-against minority.

\section{Study Objectives}

Empirical studies indicate that highly religious persons generally enjoy increased mental and physical health (Koenig et al., 2012) and longevity (Hummer, Rogers, Nam, \& Ellison, 1999)—as well as modest increases in marital satisfaction and stability, when religious involvement is shared (Mahoney, 2010). Comparatively less attention has been paid to struggles linked to religion, particularly interpersonal struggles. Our research team sought to address this gap by analyzing a national qualitative data set of 198 families with a focus on relational or interpersonal struggles. Open coding revealed several hundred examples-with sufficient quality to produce papers on two types of interpersonal/relational struggles. Our first related study explored relational struggles inside religious families (Dollahite, Marks, \& Young, 2018). The present qualitative study examines interpersonal/relational struggles with those outside of the family. We noted that such struggles were especially pronounced among the 131 religious minority families in our sample, and those families became our focal concern in the present article. Our specific objective in this study was to explore the following: What struggles (originating outside the family) do religious minority families report?

\section{Methods}

We align ourselves with the phenomenological tradition (see Daly, 2008) and qualitatively explore the phenomena of religious beliefs, practices, and communities as they impact relationships. At the foundation of our qualitative method lies the analytic of open coding, the process of examining, comparing, conceptualizing, and categorizing data, as forwarded by Strauss and Corbin (1990) in grounded theory methodology. Additionally, we employ a qualitative, narrative-focused approach (i.e., Josselson \& Lieblich, 1993) - an approach that has been recommended as an excellent fit with exploring meanings (whys) and processes (hows) at the sensitive nexus of religious faith and family relationships (Davis et al., 2016; Dollahite, Marks, Kear, Lewis, \& Stokes, 2018). Indeed, narratives often help portray what is meaningful to participants, as well as why and how meaning has been derived or created. Through narratives, meanings can become more dynamic, stretching backward and forward in time-giving the researcher a more 
fluid motion picture of meaning-making as opposed to a snapshot (Marks \& Dollahite, 2011).

\section{Sampling}

Purposive sampling methods were used (Denzin \& Lincoln, 1994). As scholars with interest in both long-term marriage and in parent-child relationships, we desired long-term marriages or remarriages with children. Religious community leaders (e.g., pastors, priests, imams, rabbis, bishops) in population centers ${ }^{1}$ where members of the research team had entrée were contacted and asked to identify strong, marriage-based families with children who were also committed to and involved in their faith. Second, these exemplar families were contacted by the researchers to determine willingness to participate. Among more difficult-to-access faiths (e.g., Islam, Orthodox Judaism), within-group participant referral sampling was sometimes employed. Geographically, 198 participant families were from 17 states in all 8 religious regions in the nation (see Silk \& Walsh, 2011), including the Mid-Atlantic (DE, MD, PA), Midwest (OH, WI), Mountain West (ID, UT), New England (MA, CT), Northwest (OR, WA), Pacific (CA), the South/ Gulf Coast (FL, GA, LA), and Southern Crossroads regions (KS, $\mathrm{OK})$. Furthermore, the families represented a wide range of socioeconomic levels. Thus, the sample was characterized by (a) high levels of religious commitment, (b) rich racial and ethnic diversity $^{2}$, (c) religious diversity, (d) geographic and regional diversity, and (e) a wide range of socioeconomic diversity (as indicated by housing and educational experience that ranged from GED to $\mathrm{PhD} / \mathrm{MD})$.

In the present article, the original sample of 198 families $(N=$ 476 individuals) has been trimmed to focus on religious minority families. The characteristics of these 131 religious minority families $(N=317$ individuals $)$ are as follows. The ages for the 131 wives were $M$ age $=47$ years; for the 131 husbands, $M$ age $=49$ years; and for the 55 adolescent children, $M$ age $=15$ years. In terms of religious affiliation, the sample included 30 Jewish families $(23 \%$ of sample, consisting of Orthodox, Conservative, and Reformed traditions), 25 Muslim families (19\% of sample, consisting of Sunni and Shia branches), 26 LDS/Mormon families (20\% of sample), and 20 Asian American Christian families (15\% of sample), with the remaining $23 \%$ comprising minority Christian faiths including, but not limited to, Quaker, Seventh-day Adventist, Jehovah's Witness, and Christian Scientist denominations.

The racial/ethnic composition of the sample was 32 African American families (24\%), 20 Asian American families (15\%), 10 Middle Eastern families (8\%), 10 Native American families (8\%), 6 Latino families (5\%), 4 East Asian families (3\%), and one Pacific Islander (1\%) family, with the 48 remaining families (37\%) identifying as racially White.

Handel (1997) has indicated that family research is often based on data from a single individual representing the family, but contends that this is not truly family research. ${ }^{3}$ Specifically, Handel has stated, "No [single] member of any family is a sufficient source of information for that family" (p. 346). In the present study, mothers, fathers, and (where possible) adolescent children were interviewed in order to gather multiple perspectives on relational struggles.

\section{Interview Procedure}

Preceding the interviews, each interview question was pretested to identify potential problems. The $30+$ questions were openended, including follow-up questions designed to clarify and add depth to the initial responses given. Topically, questions addressed marriage, parenting, family challenges, and religious life. Following their reading and signing a statement of informed consent, participants were typically interviewed in their homes. No questions explicitly asked if and how the participants' religion had created struggles, but we did ask about challenges, difficulties, harms, and potential (hypothetical) harms. Most interviews lasted about two hours. The interviews were transcribed verbatim and coded, as explained next.

\section{Coding and Analysis}

We employed a team-based approach to qualitative data analysis and coding. Our ethnically and nationally diverse six-member coding team for this article included Asian American, Polynesian American, White, and immigrant members, all members of a minority faith.

We constructed a detailed codebook to search the data systematically in order to find examples of relational struggles linked with religion reported in the more than 4,200 single-spaced pages of transcribed interview data. Coders were instructed to look for accounts of struggles linked with religion, including profound struggles (e.g., those pertaining to death, salvation, anomie, and meaninglessness) as well as more prosaic struggles_-past, present, or future. Our team was divided into coding pairs. Both individuals in a coding pair independently coded the same interviews using a struggles codebook. The two then met together to compare codes each week as a check-and-balance. Using thousands of strugglesrelated codes, we then reanalyzed and recoded these accounts and focused on struggles that seemed to directly relate to the quality or stability of relationships - and labeled these accounts as Relational Struggles Linked with Spirituality/Religion (struggles). The composite interrater reliability for the Religion Creates Struggles themes reported in this article was over .90 (themes with relatively low interrater reliability are not reported). Specifically, our team coded 1,453 accounts of various struggles, many of which involved internal or inside the family struggles (Dollahite, Marks, \& Young, 2018). Of the 1,453 accounts, 213 (15\%) involved outsidethe-family struggles from a total of 80 families $(61 \%$ of the sample). In other words, less than two-thirds of the sample shared accounts of struggles that came from outside the family, but those who did discuss these tensions tended to do so multiple times-an average of roughly 2.7 times per interview (i.e., 80 families reported 213 struggles originating outside the family). These 213

\footnotetext{
${ }^{1}$ These included, but were not limited to, Atlanta, GA; Baton Rouge, LA; Springfield, MA; Amherst, MA; Milwaukee, WI; Marin County, CA; Portland, OR; and Wilmington, DE.

${ }^{2}$ This is vital given the unique religio-cultural experiences of racial minorities (Alghafli, Hatch, \& Marks, 2014; Kim, 2017; Lu, Marks, \& Apavaloiae, 2012; Lu, Marks, \& Baumgartner, 2011; Lu, Marks, Nesteruk, Goodman, \& Apavaloaie, 2013).

${ }^{3}$ For a notable and religion-related recent exception that includes wives and husbands, see Jorgensen, Mancini, Yorgason, and Day (2016).
} 
accounts of outside of the family struggles are the focus of the present article.

We additionally employed several rigor-enhancing strategies, including (a) developing a detailed audit trail for sampling, questionnaire usage, and qualitative coding that demonstrate and provide a replicable method of inquiry (Marks, 2015); (b) building a qualitative research team that engaged team members with a diverse array of project-relevant life experience; and (c) coding the data as a team with a focus on interrater reliability $(>.90)$ in a way that allowed for multiple voices but tempered the biases of individual members.

\section{Results}

The five most prevalent struggles reported by the 131 religious minority families were (a) struggles related to difference and minority status, (b) struggles related to other religious people, (c) struggles related to misunderstanding and ignorance, (d) struggles related to the demands of faith community, and (e) struggles related to animosity and rejection. In the participant-focused approach to qualitative research we employ (see Marks, 2015), we strive to primarily present the participants' voices. All themes are supported by multiple examples from the primary data (more than 20 participant quotes).

\section{Theme 1: Struggles Related to Difference and Minority Status}

Many participants reported that their distinctiveness in religious behaviors, practices, and/or beliefs led to a variety of struggles. This source of struggle accounted for more than one in three accounts in the Relational Struggles Linked with Spirituality/ Religion data (35\%), and was coded more than any other source. Reported differences included physical distinctions such as special religious clothing, behaviors (or abstinences) that deviated from social norms, and struggles of living far from other supportive members of their own faith.

Accounts involving children or youth were coded most frequently under this source (39 accounts) and accounted for 52\% of this source. It was apparent that for the religious minority parents we interviewed, the religion-related biases they faced were one thing, but the hurts their children faced seemed to carry an amplified intensity.

Perceived differences and minority status often seemed to be internal (personal) struggles, but struggles also resulted from how people reacted to differences and interactions between their families and others. Several accounts involved persons outside the participants' religion treating persons inside the faith negatively. While the families did not suggest that the differences or their minority status be eliminated, they seemed to desire that others be more accepting, accommodating, and less judgmental of those differences. Both the differences and the reactions led many participants to feel not only different, but also isolated and excluded. Yameen $^{4}$, a Shia Muslim father, explained how differences seemed to disadvantage him professionally:

I feel since we are living in the West, that it would be easier ... to get work if I am not Muslim. There are some social aspects of things that are going on after work, meetings in bars and things like that-of course I cannot attend, and I actually do not want to attend. I do feel that this ... affects ... how much involvement I can have with them and I think it does limit me a little bit as my progression goes . . . in work.

Sometimes participants expressed struggles that arose according to how religious differences were handled. For example, Bekah, a Jewish mother, explained how her daughters have reacted with irritation to differences between themselves and others:

\begin{abstract}
There have been some difficult times with the girls, every year. . . . "Why are all the decorations for Christmas?" You know, just a lot of questions and irritation, and I understand their irritation and I've experienced it in the past, but I've gotten to a point in my life where I'm not irritated by it. I keep explaining to the girls that people are not doing this to be mean, people do not mean to be excluding other religions, they're not trying to hurt you . . . this is [just] what they do to celebrate.
\end{abstract}

Bekah highlighted a distinction between herself and her daughters; her daughters' offended reactions to feeling different created irritation for them, but Bekah herself no longer felt maligned by those who "exclude other religions." Thus, the source of struggle may not be found in difference or minority status itself, but in how religious individuals react to situations in which their differences seem highlighted. Another Jewish mother, talking about her daughter, explained, "She doesn't always like being different. No child does. But we are different and she's going to grow up knowing that and being a part of that." Indeed, most religious minority families expressed no intention of changing themselves or their environment (by relocating), or even attempting to change others to alleviate the consequences of being religiously different.

In other cases, the source for struggles was found not in how they (or others) inside the religion reacted, but in how those outside the faith reacted to the participants' minority status. Wafiyah, a Muslim mother, explained this concept by borrowing the words of her daughter:

Because I wear hijab [head covering $]^{5} \ldots$ [when I am out] in the community ... I I have to be different. I cannot be friends with everybody because their reaction to my hijab is different. I can only communicate with the friends that I have from childhood . . . [because] they know me. $[\mathrm{M}]$ aking . . . strong relationships is hard in a new community.

Here, the reactions of those outside the faith community to Wafiyah's different style of dress seemed to lead to feelings of disconnection. Differences between religious insiders and outsiders are inevitable, and while differences themselves may have resulted in some struggles, how those involved handled the differences also seemed to influence the amount of struggle experienced. We now move on to discuss struggles directly involving religion and its people.

\section{Theme 2: Struggles Related to Other Religious People}

While most participants seemed to say, "Because I am religious, I experience these struggles," the data associated with Theme 2

\footnotetext{
${ }^{4}$ All participant names are pseudonyms to protect identity.

${ }^{5}$ Brackets inside participant quotes are used sparingly and denote the authors' clarifying words, based on the contextual information from the full interview.
} 
indicated that other religious people sometimes directly caused struggles. Many accounts in this source of struggle focused on at least some of the beliefs, rules, and behaviors of their own faith communities, denominations, and subgroups-as well as aspects of religious and congregational organization (mainly their own). Participants also spoke about people living or "pushing" religion in ways that created struggles or contention between religious groups. More than one in five of the struggles-related accounts (21\%) were examples of this source. Most of the accounts of struggle in this theme were traced by participants to another religious person or to religious organizations-including the participants' own faith communities (intrafaith struggles) and other faith communities (interfaith struggles). These accounts perhaps reflect the most direct examples of religion creating relational struggles.

Reported struggles from religion and religious people included feeling excluded, divided, misunderstood, and/or offended. Some cases included betrayals of trust by fellow congregants or even leaders. Jane, a Latter-day Saint mother, recalled,

[When I was] a teenager, . . . there was a man who was in the leadership of the young men organization, who was . . . [a] young, charismatic, outgoing guy that was really a role model. There were several families of boys who didn't have a father figure at home, and [they] particularly looked up to this man. And after about a year of serving in that position he ended up cheating on his wife, and getting a divorce, and pretty well [turning] his back on everything that he ha[d] . . . taught, turning to a life of hedonism. . . . It was devastating, particularly for those boys that looked up to him so highly as an example of what they wanted to be ... and it was really heartbreaking to see the influence that he had, and how it was definitely used badly.

Angie, a convert to Islam from a Christian faith, shared a similar experience from her youth:

When I was in the $[\mathrm{X}]$ church, I hit rock bottom when my parents divorced and then the minister was publicly humiliated because he was having affairs on his wife. That was my loss in trust, my trust was totally broken and my family life was shattered all at the same time. I had no idea where to go. I wondered, how can these people lead others? . . . At that time I had hit rock bottom. I had God but I didn't have a faith

These are examples of the possible damage that may occur for youth or others who look up to imperfect leaders in a religious setting, often within their own congregation.

Other participants discussed struggles relating to observed division and contention within their own religious communities. Elijah, a Jewish father, explained a conflict with his synagogue and, in spite of his high level of involvement, reported,

I profoundly disagree with institutional Judaism. For [my wife and me], Israel/Palestine is important. It's actually caused friction between us and various Jewish friends of ours ... in the synagogue. I will open my mouth and there will be people who are very upset at me. It's a little interesting that we both feel . . . that it's so important to have a synagogue, but in some ways we do not get along with the people in the synagogue.

The ties that bind can also chafe-at faith community levels and at marital and family levels. The narratives presented in this thematic section have all addressed struggles rooted in elements within the participants' own faith communities. The next theme focuses on struggles that reportedly originated from outside the participants' own communities.

\section{Theme 3: Struggles Related to Misunderstanding and Ignorance}

Most of the highly religious families we interviewed were a pronounced religious minority in their communities. Therefore, most of those they interacted with in daily life were, to some extent, ignorant of (or misinformed regarding) the beliefs, practices, and lifestyles that the participants embraced (Prothero, 2009). Families often expressed frustrations with the misunderstanding, ignorance, and lack of awareness on the part of those outside their faith, including those who actively participated in other religions. More than one in six accounts of struggles (18\%) were coded as misunderstanding and/or ignorance.

Misunderstanding and ignorance accounts seemed to relate to feeling misjudged, incorrectly portrayed, or discriminated against. Sometimes perceived misunderstanding and ignorance led families to report feelings of offense or anger, but typically the reported result was disappointment. Eleanor, a Jewish mother and professional musician, related the following:

Playing with the symphony, we have rehearsal schedules and ... they would never ever dream of scheduling a rehearsal on a Sunday morning, ever . . . but they do not think twice about when we [Jewish persons] have our services. That's one of those challenges, I guess. They're not even sorry that they did that. I'm pretty sure it's really just a matter of ignorance, and it's not a meanness. I'm sure they do not sit around thinking how they can make it inconvenient for us, but it doesn't occur to other people to think of other people's religious holidays.

Some Muslim families spoke of misunderstanding and ignorance following the events of $9 / 11$. Some felt mistrusted, such as Baseema, a Muslim wife who said, "After September 11th you can feel it . . . they ... question you sometime[s], not with words but with their eyes." Another Muslim mother, Aisha, explained how the tragic events of $9 / 11$ have led to feeling hurt:

People think that, "Oh, Muslims, they take this lightly." We were hurt that people were hurt. So I think we were more offended that, you know, that they thought it was a form of . . . Islamic activity, which by no means it was.

As we conclude our discussion of struggles related to misunderstanding and ignorance, we note that relatively few participants addressed overt and clearly intentional actions of hatred (although some will be discussed later). Even so, expressed frustrations regarding misunderstanding and ignorance of those outside the participants' faiths were common. We now discuss how the religious expectations of one's own faith can create struggles.

\section{Theme 4: Struggles Related to the Demands of Faith Community}

Often, participants' deep involvement in their faith communities involved implicit and explicit responsibilities. One in seven (14\%) of the struggles-related accounts were coded as stemming from religious demands/expectations. Many of these examples involved the struggles to feel on par with other members of their faith 
community, a sense of responsibility within the faith community, or experiencing pressure to be an exemplar of the faith to others. Fulfilling these expectations was reportedly a struggle, and additional struggles arose when religious expectations were not met. Behavioral expectations seemed closely tied into the lives of most of these highly religious families. Most participants did not express a desire to change or remove these religious expectations. In fact, most seemed desirous, even eager, to follow their faith community's expectations, but these expectations were nevertheless described as challenging, with some participants reporting negative consequences such as feeling inadequate, stressed, guilty, uncertain, and fearful (including fear of separation from God). Rose, a Latter-day Saint mother, explained the pressures of being highly involved in her faith community:

\begin{abstract}
Being a main member of the [congregation] carries a lot of responsibility. We are responsible to support everything. If [we] weren't there [people ask], "Where were you?" I know we ... [help] keep the [congregation] going . . . and I personally feel a responsibility to be "up." . . I'm going to say "Hi" to everyone and it's kind of hard sometimes, 'cause if I'm down then I walk in . . . keeping up that support for everyone [is a struggle]. There's so much that I have to [do] and getting the three little girls [ready for church on top of that]. I really, really try. It's hard, but I want to support everything and sometimes I get overwhelmed with all the responsibilities.
\end{abstract}

Participants conveyed a range of reactions to expectations from the faith community.

Most participants did not seem to consider religious expectations solely or even primarily as a problem, and many framed them as motivational. Some, however, viewed these expectations as burdens or as doors to failure that often seemed to lead to more struggles. There is a complexity and tension here that warrants further attention. We now move to a final source of struggles.

\section{Theme 5: Struggles Related to Animosity and Rejection}

Some participants reported that sometimes persons outside their faith demonstrated negative feelings, hatred, or hostility toward them personally or toward the religious community to which they belonged. Such animosity and rejection sometimes reportedly led outsiders to persecute, harass, tease, or threaten participants or their faith communities. Such reports were relatively rare [slightly less than one in eight (12\%) of the struggles-related quotes were coded as struggles stemming from animosity or rejection]. Even so, when these accounts were reported, they were often salient and long remembered.

One striking note of animosity surrounded the (minimally publicized) suspected arson of a Mormon Church near an Oregon family the evening before their interview. The couple was calm and relatively sanguine in their response.

Interviewer: Throughout this project [we]'ve talked to different families in different parts of the country, particularly of minority religions that experienced religious bigotry or persecution at some level. News came to you . . . earlier today that a [Mormon] chapel had been burned, destroyed by arson just a little north of here, not your building, but [a] building where you have con- tacts. Could you ... describe your feelings and thoughts?

Camilla: I feel not really sure how to express it. I just hate to see any type of religious bigotry toward any religion, not just ours. I just do not like to see that type of thing happen anywhere ...

Dean: The initial diagnosis, if you will, is arson, and it may well have been . . . but I cannot really say that I've been the personal target of any bigotry. Usually when somebody asks me anything about [my] church it's from a standpoint of . . . interest [I will say this though], even if . . . one building right here ... [has] been torched . . . my religion is . . . not about buildings.

Similar expressions of hatred through apparent arson have disproportionately affected Black churches throughout recent and historical time in the United States-as well as synagogues and mosques - a reminder that true religious liberty still remains a less than fully realized ideal. Even so, the above incident was an anomaly during our $15+$ years of data collection. When it came to animosity and bigotry, most coded accounts were focused on negative portrayals and perceived attacks. Ibrahim and Jala, a Muslim couple, explained how animosity against Muslims (as expressed in popular media) has created stress for them:

Ibrahim: It's been really stressful for all Muslims. It's tough to even watch the news anymore.

Jala: It's so depressing.

Ibrahim: There is not one day that goes by without something negative about the Muslims. It's been very stressful for all of us.

Fatima, an Arab American Muslim mother, reported that "I was fired from my job when I began covering" (wearing a hijab). Ali, a Muslim father interviewed in a Southern metro area where his wife had struggled to find work, asked the interviewer if he had ever seen a Muslim woman with a hijab working in a local business. The response was measured but negative.

Ruth, while discussing the challenge of being Jewish in a medical office where "everyone" was Christian, reported, "Sometimes you feel very alone." Abigail, another Jewish mother, also offered an account that seemed to reflect some animosity: "Our son was told that he was 'going to hell' on the playground, just a couple of months ago. That's very, it's just hard."

A different perspective was captured by a mainline Christian father named Thomas who discussed relational difficulties that had been stimulated by religious differences and misunderstanding. As in Abigail's account, Thomas discussed his child's experience:

Our middle son, Jonathan . . . about five years ago ... [he was] maybe going on about four [years old]. [Jonathan] was concerned for the salvation of this little neighbor friend ... [who is] Hindu. His mother [also is] Hindu . . . but what happened was [Jonathan] tried to share his faith with him and said, "[I]f you do not believe in God, you're going to go to hell." ... His [friend's] mother was very offended by that and now they do not-[well], it's been five years and they do not play together [anymore]. That [has] hurt. 
In this narrative, it seems, everyone loses. Adult parents are unable to offer lived examples of apology, reconciliation, and forgiveness to their children. Two young boys lose a friendship. Families are divided with festering feelings. There must be a better way. We next turn to this prospect in our discussion.

\section{Discussion}

Our study explored religious minority families' struggles in their relationships with those outside their immediate or extended family. Differences between religious persons and those outside their minority faith reportedly led to struggles of feeling different, isolated, alone, excluded, and uncomfortable. In Stark and Finke's (2000) terminology, such experiences seem to illustrate tension with the outside world or dominant culture. Indeed, the vast majority of our sample (about 90\%) were highly religious and their devotion was often expensive, with expenses often including social costs. Research has further indicated that being part of a religious minority is associated with increased religious struggles of varying types (Bryant \& Astin, 2008; Dubow, Pargament, Boxer, \& Tarakeshwar, 2000). Participants' accounts portrayed struggles related to their religious minority status and the resulting inequity they feel, including an account from Yameen, who felt professionally disadvantaged as a Muslim. However, our data also suggest that struggles with difference seem not to lie solely in the difference itself, but also in how individuals and families react to difference. With this struggle, efforts by majority persons to be more informed and aware-and by minority persons to react in constructive ways - might both provide partial but positive movement toward ameliorating or minimizing struggles related to religious differences. Research from the last five years that has examined religious in-groups, out-groups, and religious ethnocentrism has captured an array of tendencies ranging from warm tolerance (e.g., loving thy neighbor) to negative and authoritarian religious stereotyping (Banyasz, Tokar, \& Kaut, 2016; Greer et al., 2014; Johnson, Rowatt, \& LaBouff, 2012; Palasinski \& Seol, 2015; Shen, Haggard, Strassburger, \& Rowatt, 2013). Indeed, religion can unite or divide (Dollahite, Marks, \& Dalton, 2018).

Our theme addressing misunderstanding and ignorance highlighted the struggle participants felt with others' lack of religious awareness. Related accounts conveyed experiences where participants felt misunderstood, misjudged, incorrectly portrayed, discriminated, offended, and/or angry. Either by choice or due to lack of opportunity, many Americans seem to be only minimally or incorrectly informed about the beliefs and practices of religious minorities (Prothero, 2009). Such persons may base their perceptions of a faith community on mass media portrayals that often focus on extremes (e.g., scandals and tragedies).

Accounts of struggles related to animosity and rejection comprised $12 \%$ of the struggles-related data, making struggles with animosity and rejection the least prevalent struggle reported in this article. However, as sometimes is the case in qualitative research, the lesser number of coded accounts may underrepresent the true salience (Marks \& Dollahite, 2011). Many of the animosity-related accounts were from years (even decades) earlier but remained in participants' thoughts.

If we make the effort to climb to the top of the empathy wall (see Hochschild, 2016; Marks \& Dollahite, 2018), perhaps we would act more sensitively. A juxtaposition of Abigail's and
Thomas's narrative accounts (at the end of the Results section) of their children's experiences, and how the parents responded in less than satisfying ways, reveals two different perspectives on similar events and brings to mind the adage, "We only know where people hit, we do not know where they aim" (Burr et al., 2012, p. 152). Is it possible that some of the pain (as experienced by Abigail and her Jewish son-and by the Hindu family in the latter narrative) could have been alleviated or prevented? Perhaps so. Of the religionrelated, relational struggles identified in this article, some are probably not changeable, but others may be.

We are reminded of the seminal finding by Baumeister, Bratslavsky, Finkenauer, and Vohs (2001) that bad is stronger than good-and that profoundly negative interactions tend to remain in human consciousness, memory, and rumination longer than positive interactions. Phrased differently, although relatively few of our participants related first-hand accounts of (religion-based) animosity and rejection, some who reported such experiences were pained deeply and lastingly. Additionally, we were remindedthrough the arson of a Mormon church in Oregon-that profoundly destructive elements of religious animosity still exist in America.

The remaining two sources of struggle, religious expectations and, lastly, other religious people, differed from the three just discussed. While the previous three primarily focused on struggles between insider participants and those outside their religion, the remaining two sources focused on struggles with God or with religious leaders and/or members within their own faith community. Accounts relating to religious demands and expectations reportedly came from struggles including living up to the expectations of God, themselves, and/or those of other faith community members. Some described these expectations as positive and motivational. Others, however, reported deleterious effects including feeling inadequate, stressed, guilty, and fearful (including fear of separation from God). In some cases, it may be that the more deeply involved a person is in a religion, the more they experience the cognitive dissonance associated with belief-behavior incongruence, which may result in self-condemnation or feelings of inadequacy (Exline, 2002). It seems that another way to explain expectations-based struggles is that a majority of highly religious persons and families at times do not feel they can fully live up to the extensive and expensive commitments their religion requires of them.

The final source of struggle, labeled other religious people, focused on conflict and frustration attributed to religion itselfparticularly fellow religionists. Namely, participant families expressed disagreement with religious doctrines, beliefs, rules, practices, and/or behaviors-including hypocrisy and violations of trust by religious leaders. In previous research (Pargament, Magyar, Benore, \& Mahoney, 2005), such sacred loss or desecration has been shown to have potentially lasting harm.

Additionally, some participants spoke about people living or pushing religion in ways that created struggles or contention between religious groups. Others expressed consternation with aspects of their own congregation's internal conflicts, difficulties, and organization. In this respect, our findings seemed to parallel those of one study that identified three types of negative interactions in faith communities: (a) conflict with fellow church members, (b) conflict between church members and pastors, and (c) conflict over church teachings (Krause 
et al., 2000). We saw multiple evidences of each these three struggles in our data.

While some reported struggles involved interpersonal/relational struggles within one's own (minority) faith community, many others came from outside. Religious bias, prejudice, and violence occur far more often than many Americans realize. According to FBI data, ${ }^{6}$ nearly $20 \%$ of the 5,818 single-bias hate crime incidents that occurred in 2015 were motivated by religious bias. This means around 1,160 acts of religiously motivated violence occurred in 2015-more than three per day. News reports involving desecration of Jewish cemeteries, bomb threats against Jewish synagogues and Muslim mosques, and arson attacks against Black churches and Mormon chapels remind us that all is not well in the American melting pot. While hate crimes are an extreme manifestation of religious intolerance, many adults, youth, and children from religious minorities experience milder but still unfortunate versions of religious intolerance.

\section{Implications for Future Research}

Exline (2002) has explained that even though religion also involves (and even causes) pain, it does not "negate the value of the pursuit" (p. 183). Nevertheless, she also asserted that because the negative may be more powerful than the positive, attention must be paid to the negative (Baumeister et al., 2001). The dualistic nature of involvement in a minority and/or high demand faith community warrants more attention (Dollahite, Marks, \& Dalton, 2018). Active engagement seems to yield both benefits and detriments - we need to know more about both phenomena and how benefits and costs interface. Additionally, very little research has been done on the possible benefits of religious struggles (for a brief review, see Pargament, Desai, \& McConnell, 2006). Researching possible ways that struggles both help and harm religious families may provide further insight. In particular, as posited and portrayed in this article, religious minorities should be a focal point of interest in future research on struggles. We include atheist, agnostic, and humanist persons and families as religious minorities and hope that high quality research will answer the call for more informed insight regarding these small but growing groups in America (McGowan, 2013). We are currently involved in this effort.

\section{Implications for Clinical Practice and Educational Settings}

In Prothero's (2009) volume Religious Literacy: What Every American Needs to Know-And Doesn't, he argued that most Americans are "profoundly ignorant" of others' religious beliefs and practices (p. 1). This ignorance, he contended, is not only unfortunate and limiting, it is also dangerous. Indeed, religious ignorance constrains our understanding at levels ranging from personal interactions to international politics.

A relevant empirical study that proffers hope reported an educational measure that may be helpful in ameliorating religionrelated ignorance, animosity, and rejection (Verkuyten \& Thijs, 2010). Notably, Verkuyten and Thijs found that more opportunities for contact with adolescents of different religions in their classroom led to better group relations. This suggests that the amount of religious diversity that people encounter in human interaction may positively influence how they relate to diverse religious people. This may apply in other settings outside of the classroom, such as workplaces, neighborhoods, and communities — as well as in clinical settings. As for clinical settings, Schechter (2015) has noted in his work with Orthodox Jews, "When treating couples and families, it is crucial that their dynamics be understood in the context of their [religious] culture" (p. 231). This understanding must commence somewhere. We draw hope from grassroots educational efforts, as reported in Verkuyten and Thijs (2010).

Our aim in this article was to inform by offering an array of religious minority insiders' perspectives. Perhaps this effort will also elicit increased empathy from an array of religious outsiders and, ideally, extend an invitation to climb up and look over to the other side of what Arlie Hochschild (2016) has referred to as the empathy wall-an "obstacle to deep understanding of another person ... that can make us feel indifferent or even hostile to those who hold different beliefs" (p. 5). Like Hochschild, we believe it is possible and enriching to occasionally cross the empathy wall and to meet and learn from others on their own sacred religiocultural ground. We have been changed by doing so — changed for good. The following are simple but pragmatic examples we have implemented as assignments in various university settings to promote visits to the other side of the empathy wall, religiously speaking, among our students: (a) take an acquaintance from a different faith to lunch and respectfully ask her/him to share meaningful beliefs and practices with you, (b) attend a worship service, ritual, or celebration outside of your own tradition, (c) formally interview an individual or couple of another faith, (d) read and/or qualitatively code interviews from persons of a diverse faith, and (e) cultivate a true friendship with a person of a diverse faith-with a humble awareness that our "vision may be best clarified and expanded by respectful interaction with those who see the world quite differently than we do" (Marks, 2012, p. 785).

\section{Conclusion}

We are confronted in this article with the reality that even in the United States of America-a nation that enjoys an expansiveness of religious freedom that has rarely been matched historically or globally_yes, even here, a deep commitment to a minority faith is expensive. Indeed, the related costs include not only time, money, effort, and energy but also a number of religion-related struggles that originate outside the family-including (but not limited to) discomforts that result from difference and minority status, strains resulting from lofty religious expectations, negative social interactions that result from misunderstanding and ignorance, and even episodes of blatant animosity and rejection.

If there is truth in the assertion "To the immature, other people are not real" (Warner, 2001, p. 49), then, conversely, persons of authentic maturity will recognize that others' humanity is as real as their own-even when the other is a religious minority. It may also be that a heightened awareness of some of the struggles faced by minority families of faith will promote more respectful, informed, and honorable interaction that authentically crosses the empathy wall.

\footnotetext{
${ }^{6}$ https://ucr.fbi.gov/hate-crime/2015.
} 


\section{References}

Abu-Raiya, H., \& Pargament, K. I. (2015). Religious coping among diverse religions: Commonalities and divergences. Psychology of Religion and Spirituality, 7, 24-33. http://dx.doi.org/10.1037/a0037652

Abu-Raiya, H., Pargament, K. I., Krause, N., \& Ironson, G. (2015). Robust links between religious/spiritual struggles, psychological distress, and well-being in a national sample of American adults. American Journal of Orthopsychiatry, 85, 565-575. http://dx.doi.org/10.1037/ort0000084

Alghafli, Z., Hatch, T., \& Marks, L. (2014). Religion and relationships in Muslim families: A qualitative examination of devout married Muslim couples. Religions, 5, 814-833. http://dx.doi.org/10.3390/rel5030814

Alghafli, Z., Marks, L. D., Hatch, T. G., \& Rose, A. H. (2017). Veiling in fear or in faith? Meanings of the Hijab to practicing Muslim wives and husbands in USA. Marriage \& Family Review, 53, 696-716. http://dx .doi.org/10.1080/01494929.2017.1297757

Banyasz, A. M., Tokar, D. M., \& Kaut, K. P. (2016). Predicting religious ethnocentrism: Evidence for a partial mediation model. Psychology of Religion and Spirituality, 8, 25-34. http://dx.doi.org/10.1037/rel000 0020

Baumeister, R. F., Bratslavsky, E., Finkenauer, C., \& Vohs, K. D. (2001). Bad is stronger than good. Review of General Psychology, 5, 323-370. http://dx.doi.org/10.1037/1089-2680.5.4.323

Becker, P. E. (1999). Congregations in conflict: Cultural models of local religious life. Cambridge, United Kingdom: Cambridge University Press. http://dx.doi.org/10.1017/CBO9780511499319

Bryant, A. S., \& Astin, H. S. (2008). The correlates of spiritual struggle during the college years. The Journal of Higher Education, 79, 1-27. http://dx.doi.org/10.1353/jhe.2008.0000

Burr, W. R., Marks, L. D., \& Day, R. (2012). Sacred matters. New York, NY: Routledge.

Burstein, P. (1991). Legal mobilization as a social movement tactic: The struggle for equal employment opportunity. American Journal of Sociology, 96, 1201-1225. http://dx.doi.org/10.1086/229653

Cantone, J. A., \& Wiener, R. L. (2017). Religion at work: Evaluating hostile work environment religious discrimination claims. Psychology, Public Policy, and Law, 23, 351-366. http://dx.doi.org/10.1037/law0000132

Daly, K. (2008). Qualitative methods for family studies and human development. Thousand Oaks, CA: Sage.

Davis, E. B., Cuthbert, A. D., Hays, L. W., Aten, J. D., Van Tongeren, D. R., Hook, J. N., . . B Boan, D. (2016). Using qualitative and mixed methods to study relational spirituality. Psychology of Religion and Spirituality, 8, 92-98. http://dx.doi.org/10.1037/re10000046

Denzin, N. K., \& Lincoln, Y. S. (Eds.). (1994). Handbook of qualitative research. Thousand Oaks, CA: Sage.

Dollahite, D. C., Marks, L. D., \& Dalton, H. (2018). How religion helps and harms families: A conceptual model of a system of dualities at the nexus of faith and family life. Journal of Family Theory \& Review, 10, 219-241. http://dx.doi.org/10.1111/jftr.12242

Dollahite, D. C., Marks, L. D., \& Goodman, M. (2004). Religiosity and families. In M. J. Coleman \& L. H. Ganong (Eds.), The handbook of contemporary families (pp. 411-431). Thousand Oaks, CA: Sage.

Dollahite, D. C., Marks, L. D., Kear, T. M., Lewis, B. M., \& Stokes, M. L. (2018). Beyond the bucket list: Identity-centered religious calling, being, and action among parents. Psychology of Religion and Spirituality, 10, 44-54. http://dx.doi.org/10.1037/re10000130

Dollahite, D. C., Marks, L. D., \& Young, K. P. (2018). Relational struggles and experiential immediacy in religious American families. Psychology of Religion and Spirituality. http://dx.doi.org/10.1037/rel0000135

Dubow, E. F., Pargament, K. I., Boxer, P., \& Tarakeshwar, N. (2000). Initial investigation of Jewish early adolescents' ethnic identity, stress and coping. The Journal of Early Adolescence, 20, 418-441. http://dx .doi.org/10.1177/0272431600020004003

Ellison, C. G., Krause, N. M., Shepherd, B. C., \& Chaves, M. A. (2009). Size, conflict, and opportunities for interaction: Congregational effects on mem- bers' anticipated support and negative interaction. Journal for the Scientific Study of Religion, 48, 1-15. http://dx.doi.org/10.1111/j.1468-5906.2009 .01426.x

Ellison, C. G., \& Lee, J. (2010). Spiritual struggles and psychological distress: Is there a dark side of religion? Social Indicators Research, 98, 501-517. http://dx.doi.org/10.1007/s11205-009-9553-3

Exline, J. J. (2002). Stumbling blocks on the religious road: Fractured relationships, nagging vices, and the inner struggle to believe. Psychological Inquiry, 13, 182-189. http://dx.doi.org/10.1207/S15327965PLI 1303_03

Exline, J. J. (2013). Religious and spiritual struggles. In J. J. Exline, K. I. Pargament, J. W. Jones, K. I. Pargament, J. J. Exline, \& J. W. Jones (Eds.), APA handbook of psychology, religion, and spirituality (pp. 459-475). Washington, DC: American Psychological Association.

Exline, J. J., Pargament, K. I., Grubbs, J. B., \& Yali, A. M. (2014). The religious and spiritual struggles scale. Psychology of Religion and Spirituality, 6, 208-222. http://dx.doi.org/10.1037/a0036465

Exline, J. J., Park, C. L., Smyth, J. M., \& Carey, M. P. (2011). Anger toward God: Social-cognitive predictors, prevalence, and links with adjustment to bereavement and cancer. Journal of Personality and Social Psychology, 100, 129-148. http://dx.doi.org/10.1037/a0021716

Greer, C. L., Worthington, E. L., Jr., Van Tongeren, D. R., Gartner, A. L., Jennings, D. J., Lin, Y., . . Ho, M. Y. (2014). Forgiveness of in-group offenders in Christian congregations. Psychology of Religion and Spirituality, 6, 150-161. http://dx.doi.org/10.1037/a0035186

Grubbs, J. B., Exline, J. J., \& Campbell, W. K. (2013). I deserve better and god knows it! Psychological entitlement as a robust predictor of anger at God. Psychology of Religion and Spirituality, 5, 192-200. http://dx.doi .org/10.1037/a0032119

Handel, G. (1997). Family worlds and qualitative family research. Marriage \& Family Review, 24, 335-348. http://dx.doi.org/10.1300/J002v24n03_06

Hochschild, A. R. (2016). Strangers in their own land. New York, NY: The New Press.

Hummer, R. A., Rogers, R. G., Nam, C. B., \& Ellison, C. G. (1999). Religious involvement and U.S. adult mortality. Demography, 36, 273 285. http://dx.doi.org/10.2307/2648114

James, W. (1997). The varieties of religious experience. New York: Touchstone. (Original work published 1902)

Johnson, M. K., Rowatt, W. C., \& LaBouff, J. P. (2012). Religiosity and prejudice revisited: In-group favoritism, out-group derogation, or both? Psychology of Religion and Spirituality, 4, 154-168. http://dx.doi.org/ 10.1037/a0025107

Jorgensen, B. L., Mancini, J. A., Yorgason, J., \& Day, R. (2016). Religious beliefs, practices, and family strengths: A comparison of husbands and wives. Psychology of Religion and Spirituality, 8, 164-174. http://dx .doi.org/10.1037/rel0000052

Josselson, R. J., \& Lieblich, A. (1993). The narrative study of lives. Newbury Park, CA: Sage.

Kim, P. Y. (2017). Religious support mediates the racial microaggressions-mental health relation among Christian ethnic minority students. Psychology of Religion and Spirituality, 9, 148-157. http:// dx.doi.org/10.1037/rel0000076

Koenig, H. G., King, D. E., \& Carson, V. B. (2012). Handbook of religion and health (2nd ed.). New York, NY: Oxford University Press.

Krause, N., Chatters, L. M., Meltzer, T., \& Morgan, D. L. (2000). Negative interaction in the church. Review of Religious Research, 41, 510-533. http://dx.doi.org/10.2307/3512318

Lu, Y., Marks, L. D., \& Apavaloiae, L. (2012). Chinese immigrant families and Christian faith community. Family and Consumer Sciences Research Journal, 41, 118-130. http://dx.doi.org/10.1111/fcsr.12002

Lu, Y., Marks, L. D., \& Baumgartner, J. (2011). "The compass of our life": A qualitative study of marriage and faith among Chinese immigrants. Marriage \& Family Review, 47, 125-148. http://dx.doi.org/10.1080/ 01494929.2011.571633 
Lu, Y., Marks, L. D., Nesteruk, O., Goodman, M., \& Apavaloaie, L. (2013). Faith, conversion, and challenge. Journal of Comparative Family Studies, 44, 227-247.

Mahoney, A. (2010). Religion in families 1999 to 2009: A relational spirituality framework. Journal of Marriage and Family, 72, 805-827. http://dx.doi.org/10.1111/j.1741-3737.2010.00732.x

Marks, L. D. (2006). Religion and family relational health: An overview and conceptual model. Journal of Religion and Health, 45, 603-618. http://dx.doi.org/10.1007/s10943-006-9064-3

Marks, L. (2012). "We see what we seek": A rejoinder to the responses of Amato, Eggebeen, and Osborne. Social Science Research, 41, 784-785. http://dx.doi.org/10.1016/j.ssresearch.2012.05.001

Marks, L. (2015). A pragmatic, step-by-step guide for qualitative methods: Capturing the disaster and long-term recovery stories of Katrina and Rita. Current Psychology, 34, 494-505. http://dx.doi.org/10.1007/s12144-0159342-x

Marks, L., \& Dollahite, D. (2011). Mining the meanings and pulling out the processes from psychology of religion's correlation mountain. Psychology of Religion and Spirituality, 3, 181-193. http://dx.doi.org/10.1037/ a0022206

Marks, L. D., \& Dollahite, D. C. (2018). Surmounting the empathy wall: Deep respect and holy envy in qualitative scholarship. Marriage and Family Review. Advance online publication. http://dx.doi.org/10.1080/ 01494929.2018.1469578

McConnell, K. M., Pargament, K. I., Ellison, C. G., \& Flannelly, K. J. (2006). Examining the links between spiritual struggles and symptoms of psychopathology in a national sample. Journal of Clinical Psychology, 62, 1469-1484. http://dx.doi.org/10.1002/jclp.20325

McGowan, D. (2013). Atheism for dummies. Mississauga, Ontario, Canada: Wiley Canada.

Palasinski, M., \& Seol, K. O. (2015). Examination of religious identity meta-stereotypes when defying its relevant source through out-group helping. Psychology of Religion and Spirituality, 7, 80-89. http://dx.doi .org/10.1037/a0037622

Pargament, K. I., Desai, K. M., \& McConnell, K. M. (2006). Spirituality: A pathway to posttraumatic growth or decline? In L. G. Calhoun \& R. G. Tedeschi (Eds.), Handbook of posttraumatic growth: Research and practice (pp. 121-137). Mahwah, NJ: Erlbaum.

Pargament, K. I., Magyar, G. M., Benore, E., \& Mahoney, A. (2005). Sacrilege: A study of sacred loss and desecration and their implications for health and well-being in a community sample. Journal for the
Scientific Study of Religion, 44, 59-78. http://dx.doi.org/10.1111/j.14685906.2005.00265.x

Pirutinsky, S., Rosmarin, D. H., Pargament, K. I., \& Midlarsky, E. (2011). Does negative religious coping accompany, precede, or follow depression among Orthodox Jews? Journal of Affective Disorders, 132, 401405. http://dx.doi.org/10.1016/j.jad.2011.03.015

Pirutinsky, S., Schechter, I., Kor, A., \& Rosmarin, D. (2015). Family size and psychological functioning in the Orthodox Jewish community. Mental Health, Religion \& Culture, 18, 218-230. http://dx.doi.org/10.1080/ 13674676.2015.1042851

Prothero, S. R. (2009). Religious literacy: What every American needs to know-And doesn't. New York, NY: Harper One.

Schechter, I. (2015). Socioreligious and clinical landscapes of couplehood and families in Orthodox Jewish communities. In S. Kelly (Ed.), Diversity in couple and family therapy (pp. 231-257). Santa Barbara, CA: Praeger.

Shen, M. J., Haggard, M. C., Strassburger, D. C., \& Rowatt, W. C. (2013). Testing the love thy neighbor hypothesis: Religiosity's association with positive attitudes toward ethnic/racial and value-violating out-groups. Psychology of Religion and Spirituality, 5, 294-303. http://dx.doi.org/ 10.1037/a0033648

Silk, M., \& Walsh, A. (2011). One nation, divisible. Lanham, MD: Rowman \& Littlefield.

Stark, R., \& Finke, R. (2000). Acts of faith. Berkeley, CA: University of California Press.

Strauss, A., \& Corbin, J. (1990). Basics of qualitative research. Newbury Park, CA: Sage.

Verkuyten, M., \& Thijs, J. (2010). Religious group relations among Christian, Muslim and nonreligious early adolescents in the Netherlands. The Journal of Early Adolescence, 30, 27-49. http://dx.doi.org/10.1177/ 0272431609342984

Warner, C. T. (2001). Bonds that make us free. Salt Lake City, UT Shadow Mountain Press.

Wilt, J. A., Grubbs, J. B., Exline, J. J., \& Pargament, K. I. (2016). Personality, religious and spiritual struggles, and well-being. Psychology of Religion and Spirituality, 8, 341-351. http://dx.doi.org/10.1037/rel 0000054

Received June 16, 2017

Revision received April 11, 2018

Accepted May 14, 2018 